\title{
Temporal pattern in basal area prediction error of a growth model for Quebec's temperate forest
}

\author{
by Hugues Power1," and Isabelle Auger1
}

\begin{abstract}
Forest growth models are essential for forest management and the elaboration of forest policies. For model users, assessing the performance and the reliability of a model is essential. Hence, validation is an important step of model development. However, species-specific and observation year-related patterns in model error are rarely reported, although the ongoing changes in growth conditions are likely to increase the presence of such patterns. In this study, we analyzed the basal area prediction error of Artemis, a single-tree empirical growth model. Even if the model's basal area predictions were unbiased in most conditions, we detected species- and observation year-related patterns in prediction errors. These trends were strongest for sugar maple (Acer saccharum Marsh.), for which a shift occurred from underestimation in 1975 to overestimation in 2010, and for balsam fir (Abies balsamea (L.) Mill.), for which a shift occurred from overestimation to underestimation over the same period. A better consideration by the model of soil, climate and pest disturbances could contribute to reducing model bias. These results are relevant for both developers and users, who should be aware that predictions for these species are likely to be increasingly biased as the length of the projection period increases.
\end{abstract}

Keywords: forest growth model, validation process, sugar maple, balsam fir, American beech

\begin{abstract}
RÉSUMÉ
Pour les utilisateurs, l'évaluation des performances et de la fiabilité d'un modèle de croissance est essentielle. Cependant, les biais spécifiques à l'espèce et à l'année d'observation sont rarement signalés, bien que des changements dans les conditions de croissance soient susceptibles d'augmenter la présence de tels biais dans les modèles. Dans cette étude, nous avons analysé l'erreur de prévision de la surface terrière d'Artemis, un modèle de croissance à l'échelle de l'arbre. Même si les prévisions du modèle étaient peu biaisées dans la plupart des conditions, nous avons détecté des tendances liées à l'espèce et à l'année d'observation. Ces tendances étaient les plus fortes pour l'érable à sucre (Acer saccharum Marsh.), pour lequel une sous-estimation de la surface terrière en 1975 évoluait vers une surestimation en 2010. Pour le sapin baumier (Abies balsamea (L.) Mill.), la tendance contraire a pu être observée. Une meilleure prise en compte par le modèle des conditions de croissance et des perturbations biotiques pourrait aider à diminuer les biais. Ces résultats sont pertinents pour les développeurs et pour les utilisateurs, qui doivent savoir que les prévisions du modèle de croissance pour ces deux espèces sont susceptibles d'être de plus en plus biaisées avec l'allongement de la période de simulation.
\end{abstract}

Mots clés: modèles de croissance forestière, processus de validation, érable à sucre, sapin baumier, hêtre à grandes feuilles

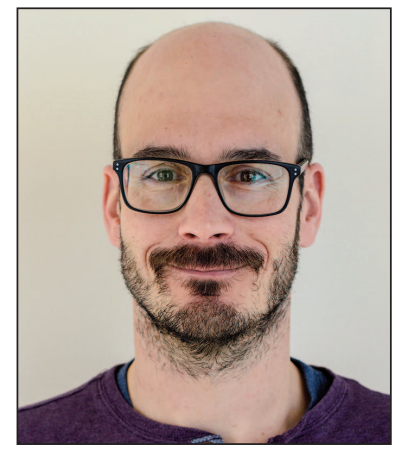

Hugues Power

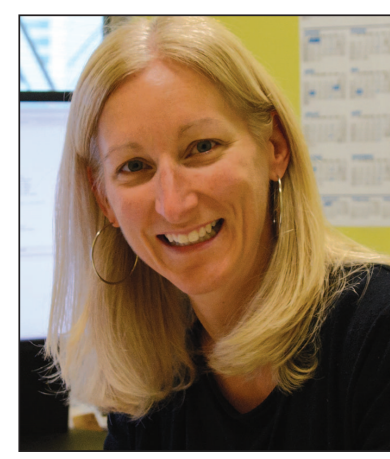

Isabelle Auger

\section{Introduction}

For many years, forest managers have relied on various forest growth models to guide their decisions (Condés and GarciaRobredo 2012). Yield tables, which predict stand characteristics over a period of time often corresponding to a tree cohort rotation, can be considered as the first type of model. They have been used for over 200 years in different parts of the world (Pretzsch et al. 2008). Over the years, yield tables have evolved toward empirical growth models, which are based on statistical relationships between growth and explanatory variables related to tree dimensions, competition or growth conditions (Korzukhin et al. 1996). These tools are often based on repeated measurements of sample plots and integrated in software to facilitate their use by forest managers.

\footnotetext{
${ }^{1}$ Direction de la recherche forestière, Ministère des Forêts, de la Faune et des Parcs du Québec, Québec (Quebec) G1P 3W8, Canada;

*Corresponding author: hugues.power@mffp.gouv.qc.ca
} 
Empirical growth models are popular for different reasons. They are relatively simple and can be used with data that are commonly available through traditional forest inventories-two characteristics that guarantee them a broad range of applications (Fontes et al. 2010). Although empirical models are generally considered reliable and precise when used in conditions similar to those that prevailed during their calibration, their predictions can be biased when used in a different context (Ex and Smith 2014).

Over the last decades, eastern North American temperate forests have experienced successive disturbances that are likely to induce changes in tree growth and stand composition. Sugar maple (Acer saccharum Marsh.), among the most abundant tree species of the northeastern temperate hardwood forest, experienced dieback in the 1980s and into the 1990s in certain locations. This dieback was observed in Quebec (Duchesne et al. 2003), in Ontario (Miller and Watmough 2009) and at different locations in the eastern United States (Bal et al. 2015). At the same time, over the last 30 years, the abundance of American beech (Fagus grandifolia Ehrh.) has increased to the detriment of sugar maple in hardwood forests of Quebec (Duchesne and Ouimet 2009) and in parts of the northeastern United States (Nyland et al. 2006). In addition, management practices have changed over the last decades. Diameter-limit cuts, sometimes associated with high grading, were widely practiced in Quebec's temperate forests until the late 1980s (Bédard and Majcen 2003). Since then, they have been replaced by single-tree selection and irregular shelterwood cuts, which leave residual stands with structural characteristics that are closer to those of old-growth forests, but which also favor the establishment of American beech saplings (Angers et al. 2005). Like other ecosystems, eastern North American temperate forests are currently affected by climate change. Since 1960, mean annual temperature as well as autumnal and spring precipitations have increased over this territory, a trend that is expected to continue during the current century (Ouranos 2015).

Other temperate forest species have experienced periodic disturbances over the last century. For instance, the spruce budworm (Choristoneura fumiferana Clem.) affected balsam fir (Abies balsamea (L.) Mill.) in the northern part of the temperate forest from the mid-1960s to the early 1990s (MacLean et al. 2002). To a lesser extent, spruce budworm also defoliates white spruce (Picea glauca (Moench) Voss) and black spruce (Picea mariana (Mill.) B.S.P.), reducing diameter growth of the defoliated trees (Pothier et al. 2005) and, ultimately, causing tree death (Pothier and Mailly 2006). Consequently, spruce budworm defoliation over large territories eventually leads to a loss of harvested wood volumes and stored carbon (Hennigar and MacLean 2010). Since 2005, another spruce budworm outbreak is underway in northern Quebec, with the potential to affect large parts of eastern Canada (MacLean et al. 2019).

In Quebec and many other forest jurisdictions, the annual allowable cut is established based on forest growth model predictions. This calculation, which is crucial to sustainable forest management, relies on growth and yield simulations over several decades. Artemis is a single-tree empirical growth model used to simulate diameter growth, mortality and recruitment in Quebec's temperate forests (Fortin and Langevin 2010). The model's predictions were found to be mostly unbiased for sugar maple-yellow birch and balsam fir-yellow birch stands over a period of 30 to 40 years (Power 2016). Despite this, biases related to observation year, possibly induced by changes in growth conditions, could have gone unnoticed during model validation. These hidden biases could contribute to increasing prediction error for longer simulation periods.

Validation is an important step of model development, because it provides information on the reliability and precision that can be expected from model predictions (Bokalo et al. 2013). Model validation is also essential to ensure user confidence in model predictions (Yang et al. 2004). A model's validation process should consider both its qualitative and quantitative aspects. Qualitative validation should focus on the biological realism of the model and include a critical analysis of its underlying logic (Soares et al. 1995). Quantitative validation of a model's predictions can include different parametric and non-parametric statistical tests (for example, the t-test, Chi-squared test, F test, or the Kolmogorov-Smirnov test), but their utility is often limited (Yang et al. 2004). Characterizing model error (Vanclay and Skovsgaard 1997) and calculating mean bias, precision and accuracy of a model's predictions are other essential steps of the quantitative validation process (Pretzsch 2009), and are necessary for a decision support tool to be useful (Stage et al. 2003). Quantitative validation should be performed for the whole model as well as for each of its components. Model validation should also include a characterization of errors according to the length of projections and year of measurement (Weiskittel et al. 2011). However, this aspect is rarely addressed, because observations are often only available for a short period (e.g., Penner et al. 2008).

The objective of this study was to test if the prediction errors for plot basal area (BA) of Artemis, a single-tree empirical growth model, present observation year-related patterns, and if these patterns vary among tree species and model components. We hypothesized that changes in growth conditions and management practices during the calibration period would induce a pattern in the BA prediction error that could be related to observation year. We also hypothesized that this pattern varied among species and model components.

\section{Material and methods \\ Data}

We selected a total of 1845 permanent sample plots (PSPs) from Quebec's national forest inventory database (MFFP 2014) (Table 1). All the selected PSPs are located in Quebec's temperate forest, between longitudes $64^{\circ} 00^{\prime} \mathrm{W}$ and $79^{\circ} 30^{\prime} \mathrm{W}$ and between latitudes $45^{\circ} 00^{\prime}$ and $49^{\circ} 30^{\prime} \mathrm{N}$ (Fig. 1). The selected PSPs are located on either the sugar maple-yellow birch (FE3) or the balsam fir-yellow birch (MJ2) potential vegetation, the two most abundant potential vegetation types of Quebec's temperate forest. A potential vegetation is defined as an ecological classification unit in which stands reach the same composition at the final stage of succession (MRNFP 2003). Among the selected plots, the most abundant tree species were sugar maple, red maple (Acer rubrum L.), American beech, balsam fir, yellow birch (Betula alleghaniensis Britt.), trembling aspen (Populus tremuloides Michx.) and paper birch (Betula papyrifera Marsh.) (Table 2). Most of the plots are located in uneven-aged or irregular for- 
Table 1. Characteristics of permanent sample plots (PSPs) at the beginning of a growth period (minimum and maximum presented in parentheses]

\begin{tabular}{|c|c|c|c|c|c|c|}
\hline $\begin{array}{l}\text { Potential } \\
\text { vegetation }\end{array}$ & Number of PSPs & $\begin{array}{l}\text { Number of } \\
\text { growth periods }\end{array}$ & $\begin{array}{c}\text { Mean observation } \\
\text { year of a growth } \\
\text { period }\end{array}$ & $\begin{array}{c}\text { Mean basal area } \\
\left(\mathrm{m}^{2} / \mathrm{ha}\right)\end{array}$ & $\begin{array}{c}\text { Mean stem } \\
\text { density (stems/ha) }\end{array}$ & $\begin{array}{l}\text { Mean quadratic } \\
\text { mean dbh }(\mathrm{cm})\end{array}$ \\
\hline $\begin{array}{l}\text { Sugar maple- } \\
\text { yellow birch (FE3) }\end{array}$ & $\begin{array}{c}966 \\
-\end{array}$ & $\begin{array}{c}2425 \\
-\end{array}$ & $\begin{array}{c}1991 \\
(1974-2013)\end{array}$ & $\begin{array}{c}20.7 \\
(0.2-51.0)\end{array}$ & $\begin{array}{c}571 \\
(25-1875)\end{array}$ & $\begin{array}{c}22.2 \\
(9.4-55.8)\end{array}$ \\
\hline $\begin{array}{l}\text { Balsam fir-yellow } \\
\text { birch (MJ2) }\end{array}$ & 879 & 2360 & $\begin{array}{c}1992 \\
(1974-2013)\end{array}$ & $\begin{array}{c}18.0 \\
(0.2-59.6)\end{array}$ & $\begin{array}{c}676 \\
(25-2150)\end{array}$ & $\begin{array}{c}19.1 \\
(9.1-50.4)\end{array}$ \\
\hline
\end{tabular}

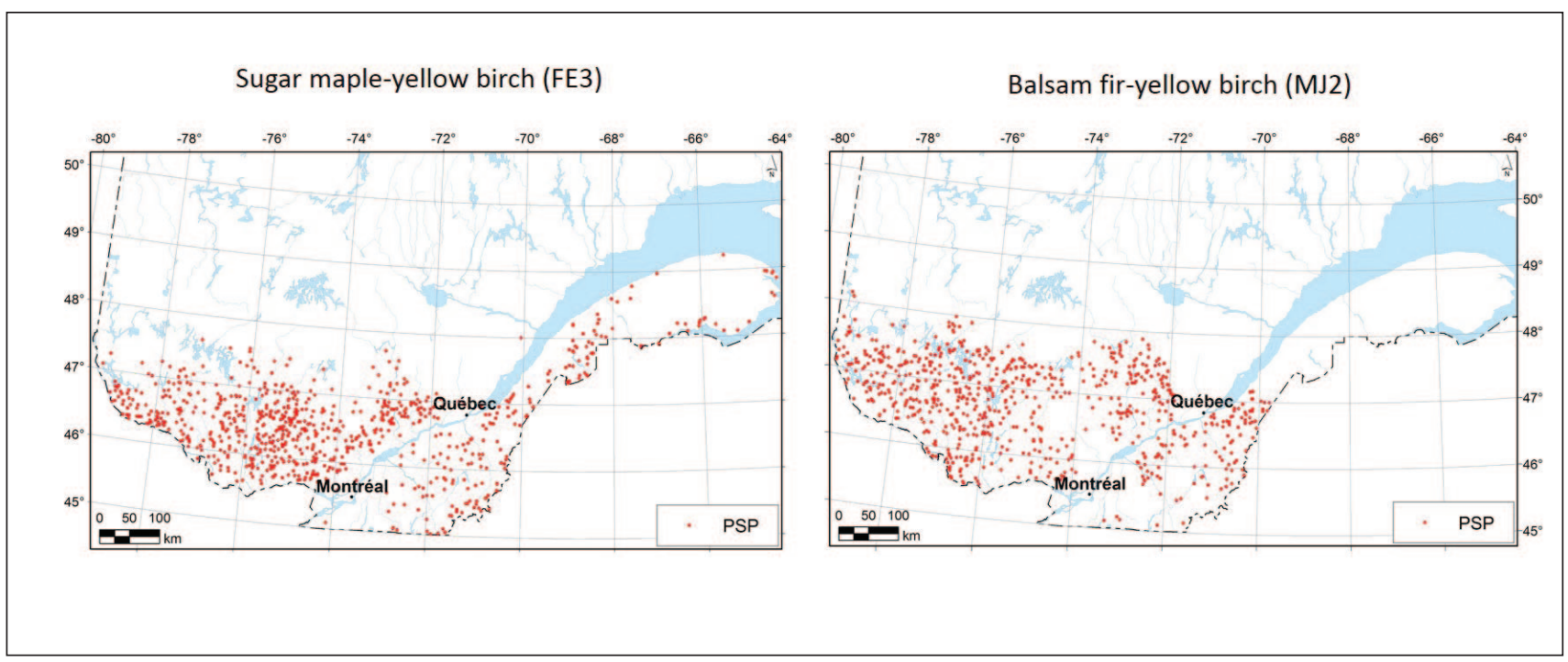

Fig. 1 Distribution of the permanent sample plots (PSPs) selected for each of the two potential vegetations.

Table 2. Mean (minimum - maximum) basal area (BA) for the five most abundant species and for all species in the selected plots, by potential vegetation

\begin{tabular}{|c|c|c|c|c|c|c|}
\hline $\begin{array}{l}\text { Potential } \\
\text { vegetation }\end{array}$ & $\mathrm{Nu}$ & $\begin{array}{r}\text { Number of } \\
\text { observed } \\
\text { growth } \\
\text { periods }\end{array}$ & $\begin{array}{r}\text { Total BA at the } \\
\text { beginning of } \\
\text { the period } \\
\left(\mathrm{m}^{2} / \mathrm{ha}\right)\end{array}$ & $\begin{array}{r}\text { 10-years } \\
\text { BA increment } \\
\text { of surviving trees } \\
\left(\mathrm{m}^{2} / \mathrm{ha}\right)\end{array}$ & $\begin{array}{r}\text { 10-years } \\
\text { BA mortality } \\
\left(\mathrm{m}^{2} / \mathrm{ha}\right)\end{array}$ & $\begin{array}{r}\text { 10-years } \\
\text { BA recruitment } \\
\left(\mathrm{m}^{2} / \mathrm{ha}\right)\end{array}$ \\
\hline \multirow{6}{*}{$\begin{array}{l}\text { Sugar maple- } \\
\text { yellow birch (FE3) }\end{array}$} & American beech & 812 & $5.0(0.2-28.2)$ & $1.0(0.0-5.8)$ & $0.7(0.0-12.7)$ & $0.1(0.0-3.8)$ \\
\hline & Balsam fir & 1064 & $2.4(0.2-20.2)$ & $0.6(0.0-5.8)$ & $1.0(0.0-18.5)$ & $0.2(0.0-7.9)$ \\
\hline & Red maple & 1135 & $3.8(0.2-24.9)$ & $0.8(0.0-5.3)$ & $0.6(0.0-13.7)$ & $0.1(0.0-9.2)$ \\
\hline & Sugar maple & 2300 & $10.4(0.2-39.0)$ & $1.9(0.0-9.2)$ & $1.0(0.0-47.9)$ & $0.3(0.0-5.6)$ \\
\hline & Yellow birch & 1405 & $4.5(0.2-27.1)$ & $0.7(0.0-5.7)$ & $0.6(0.0-15.2)$ & $0.1(0.0-6.7)$ \\
\hline & All species & 2425 & $20.7(0.2-51.0)$ & $3.8(0.0-10.7)$ & $2.9(0.0-59.7)$ & $1.1(0.0-14.1)$ \\
\hline \multirow{6}{*}{$\begin{array}{l}\text { Balsam fir- } \\
\text { yellow birch (MJ2) }\end{array}$} & Balsam fir & 1870 & $4.5(0.2-39.7)$ & $1.1(0.0-11.5)$ & $1.9(0.0-32.0)$ & $0.9(0.0-13.8)$ \\
\hline & Red maple & 1357 & $3.8(0.2-23.3)$ & $0.9(0.0-9.8)$ & $0.5(0.0-6.7)$ & $0.3(0.0-6.4)$ \\
\hline & Trembling aspen & 672 & $6.5(0.2-31.2)$ & $1.6(0.0-12.3)$ & $1.4(0.0-16.1)$ & $0.1(0.0-13.4)$ \\
\hline & White birch & 1668 & $4.7(0.2-27.3)$ & $0.8(0.0-5.8)$ & $0.8(0.0-14.9)$ & $0.2(0.0-6.6)$ \\
\hline & Yellow birch & 1203 & $5.4(0.2-30.4)$ & $0.9(0.0-6.2)$ & $0.5(0.0-12.2)$ & $0.1(0.0-5.5)$ \\
\hline & All species & 2360 & $18.0(0.2-59.6)$ & $3.6(0.0-14.8)$ & $3.6(0.0-33.9)$ & $1.9(0.0-20.5)$ \\
\hline
\end{tabular}


est stands, and 523 of the 1845 PSPs were treated by partial cuts between 1970 and 2016.

PSPs are circular plots (area: $400 \mathrm{~m}^{2}$ ) that were established between 1970 and 2011. Since then, they have been measured two to six times according to a periodic schedule, usually every 10 years. At the first measurement, all living trees with a diameter at breast height ( $\mathrm{dbh}$, measured $1.3 \mathrm{~m}$ above the ground) larger than $9.0 \mathrm{~cm}$ were numbered and measured with a diameter tape. Tree species were recorded, and potential vegetation was determined according to Quebec's hierarchical ecological classification. At each subsequent measurement, dbh of all living numbered trees was measured. Those that had died or that had been cut during the growth interval were also recorded. New recruits (trees having reached a dbh larger than $9.0 \mathrm{~cm}$ ) were also numbered and measured. We calculated plot BA for each measurement by summing the BA of every living tree with a dbh larger than $9.0 \mathrm{~cm}$. We registered the median year between two consecutive measurements as the observation year of the simulation period ( $\mathrm{Yr}$ ).

\section{Model}

We used the 2014 version of Artemis (Fortin and Langevin 2010; Power 2016) to simulate tree growth in the selected PSPs. The model was calibrated with 12000 PSPs measured periodically from 1970 to 2016, including the 1845 plots used in this analysis. Artemis is composed of four dynamic components that estimate tree mortality, dbh growth, stem quality evolution and tree recruitment of stems with a dbh greater than $9.0 \mathrm{~cm}$ (Fig. 2). The model also includes a binary variable to account for plots that had been treated by partial cuts. Three static components are included to estimate tree height,

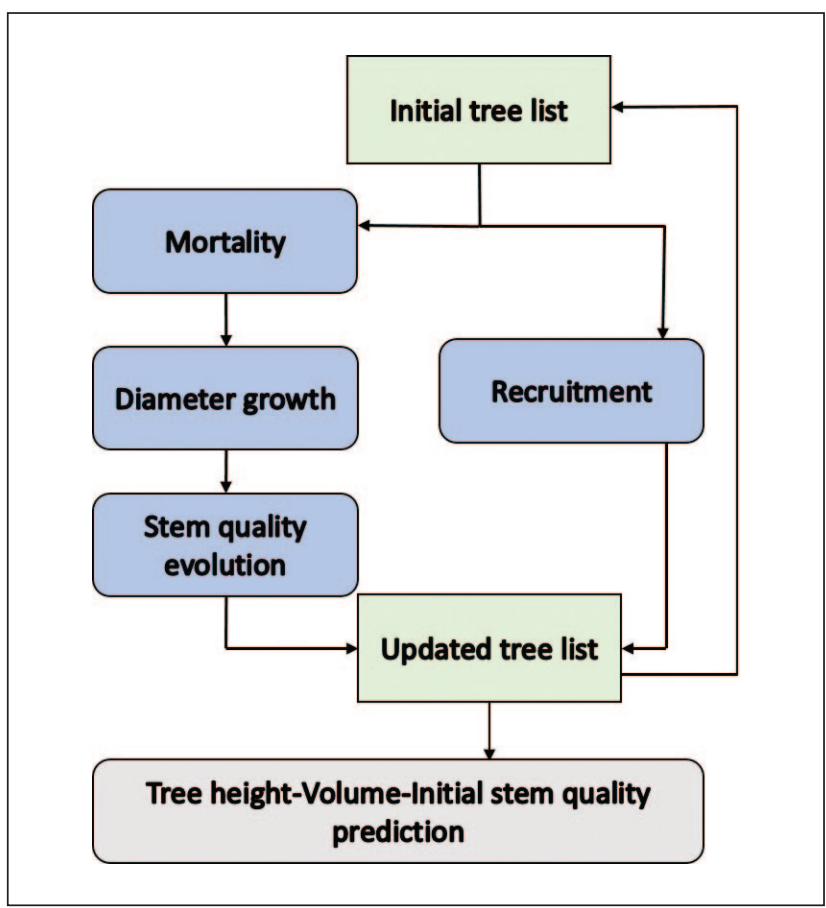

Fig. 2 Schematic representation of the model components in the 2014 version of Artemis. merchantable tree volume and initial stem quality, when these are not provided. Each potential vegetation has its own parameters for the components associated with diameter growth, mortality and recruitment. The model is implemented on the CAPSIS platform (Dufour-Kowalski et al. 2012).

For each growth period (time interval between two consecutive measurements of a PSP), the model was initialized with trees and plot characteristics measured at the beginning of the period. We simulated plot evolution for the time interval between the beginning and the end of each growth period. We estimated plot basal area prediction error (BAE) by calculating the difference between the BA observed at the end of the growth period and its predicted value. For comparison purposes, since growth periods varied from four to 37 years ( mean $=10.3$; standard deviation $=3.3$ years), BAE was scaled back to a common 10-year period (Eq. 1). BAE was estimated for all species taken together, as well as for each species (BAEsp) that accounted for at least $5 \%$ of mean plot BA.

$$
B A E_{i}=\left(\frac{y_{i}-\hat{y}_{i}}{t_{i}} \times 10\right)
$$

where $B A E_{i}$ is the 10 -year prediction error of observation $i, y_{i}$ is the observed basal area, $\hat{y}_{i}$ is the predicted basal area, and $t_{i}$ is the number of years of the growth period

For each potential vegetation, we also estimated BAEsp attributable to the model's mortality, diameter growth and recruitment components. We estimated bias (mean BAE and BAEsp) and root mean square error (RMSE) for all the variables mentioned above.

\section{Statistical analysis}

Visual examination of BAE graphics for different variables did not reveal any non-linear trends in the relationships. Because there were one to five repeated measurements for each PSP, we fitted linear mixed models with PSP as a random effect to analyze the relationship between BAE and observation year (Yr). Since the first and last years of growth periods were distributed uniformly along the monitoring period (supplementary material S1), we treated Yr as a continuous variable. In a first analysis (Eq. 2), we explored the relationship between $\mathrm{BAE}$ and $\mathrm{Yr}$, while accounting for potential vegetation $(\mathrm{Pv}), \mathrm{BA}$ at the beginning of the period, the duration of the growth interval (Dt) and the occurrence of a partial cut before the growth interval $(\mathrm{Ct})$. In a second group of analyses, we explored the relationship between BAEsp and Yr, while accounting for BA, Dt and Ct at the beginning of the period, for each potential vegetation (Eq. 3). Equation 3 was used to analyze total BAEsp and BAEsp for each model component (mortality, dbh growth and recruitment). All second-order interactions between variables were included in all analyses.

$$
\begin{aligned}
& B A E_{i j}=\mathbf{x}_{i j} \boldsymbol{\alpha}+u_{i}+u_{i j}+\varepsilon_{i j} \\
& B A E s p_{i j k}=\mathbf{x}_{i j k} \boldsymbol{\beta}+u_{i}+u_{i j}+\varepsilon_{i j k}
\end{aligned}
$$

where $\mathbf{x}_{i j}$ and $\mathbf{x}_{i j k}$ are vectors of explanatory variables, $\alpha$ and $\beta$ 
are vectors of fixed effects parameters, $\mu$ are random effects $\left(\mu_{i} \sim N\left(0, \sigma_{\text {plot }}^{2}\right), \mu_{i j} \sim N\left(0, \sigma^{2}\right.\right.$ plot-measrement $\left.)\right)$ and $\varepsilon$ is the residual error of the model $\left(\varepsilon_{i j k} \sim N\left(0, \sigma^{2}\right.\right.$ residual $\left.)\right)$. Subscripts $i, j$ and $k$ account respectively for the plot, measurement and species hierarchical levels.

We used a backward selection method to select a final model that minimized the Akaike criterion (Akaike 1973). Visual examination of the model's residual plots did not show heteroscedasticity or a lack of fit that would have indicated a non-linear trend in the relationship between the dependent variable and its predictors. Visual examination of plots of the model's residuals and random effects did not show non-normality. Models were fitted using the SAS/STAT 15.1 MIXED procedure (SAS Institute Inc. 2018). All results are presented with the BA covariate fixed at $20 \mathrm{~m}^{2} /$ ha (mean value), Dt fixed at 10.3 years (mean value) and $\mathrm{Ct}$ fixed at 0 (mode; no occurrence of a partial cut before the growth interval), when the covariates were retained in the final models. In the next section, all predicted values for BAE (obtained from Eq. 2) and for BAEsp (obtained from Eq. 3) are presented with their standard error (predicted BAE or BAEsp \pm se)

\section{Results}

Overall, the 10-year biases of predicted BA for the two potential vegetations were small (Table 3 ). For the MJ2 potential vegetation, total bias is estimated at $0.11 \mathrm{~m}^{2} / \mathrm{ha}$ and RMSE, at $4.5 \mathrm{~m}^{2} /$ ha, while for the FE3 potential vegetation, total bias is estimated at $0.03 \mathrm{~m}^{2} / \mathrm{ha}$ and RMSE, at $4.8 \mathrm{~m}^{2} / \mathrm{ha}$. Components with the largest biases were recruitment and dbh growth for the MJ2 potential vegetation, and recruitment for the FE3 potential vegetation. The mortality component had the largest RMSE.

\section{Relationship between observation year and total basal area prediction error}

We found significant relationships between BAE and $\mathrm{Yr}$ $(F$ value $=14.7, P$ value $<0.001), \mathrm{Ct}(F$ value $=50.1$, $P$ value $<0.001)$, potential vegetation $(F$ value $=50.1$, $P$ value $<0.001)$ and the interaction between $Y r$ and potential vegetation $(F$ value $=50.1, P$ value $<0.001)$. For the MJ2 potential vegetation, the predicted $\mathrm{BAE}$ of the growth periods that do not follow a partial cut evolved from $-0.8 \pm 0.2 \mathrm{~m}^{2} / \mathrm{ha}$ in 1975 to $1.2 \pm 0.2 \mathrm{~m}^{2} /$ ha in 2010 . This represents a shift from over- to underestimation of BA during the monitoring period (Fig. 3). For the FE3 potential vegetation, predicted $\mathrm{BAE}$ varied less over the same period (from $0.5 \pm 0.2$ to $-0.1 \pm 0.2 \mathrm{~m}^{2} / \mathrm{ha}$ ). For growth periods that follow a partial cut, predicted BAE evolved from $-1.6 \pm 0.3 \mathrm{~m}^{2} /$ ha in 1975 to $0.4 \pm 0.2 \mathrm{~m}^{2} /$ ha in 2010 for potential vegetation MJ2, and from $-0.3 \pm 0.3 \mathrm{~m}^{2} /$ ha to $-0.9 \pm 0.2 \mathrm{~m}^{2} /$ ha over the same period for potential vegetation FE3 (supplementary material S2).

Relationship between observation year and species basal area prediction error for each potential vegetation

We found that BAEsp varied according to $\mathrm{Yr}$ and $\mathrm{Ct}$ for both potential vegetations, and according to BA for the MJ2 potential vegetation (Table 4). For the FE3 potential vegetation and growth periods that do not follow a partial cut, sugar

Table 3. Model bias, relative bias and root mean square error (RMSE) for change in plot basal area (BA) at the end of the growth period and for each of the model components (dbh growth, mortality and recruitment), for the 5 most abundant species and for all species, by potential vegetation

\begin{tabular}{|c|c|c|c|c|c|c|c|c|c|c|c|c|c|}
\hline \multirow[b]{2}{*}{$\begin{array}{l}\text { Potential } \\
\text { vegetation }\end{array}$} & \multirow[b]{2}{*}{ Species } & \multicolumn{3}{|c|}{$\begin{array}{l}\text { BA at the end of } \\
\text { the growth period }\end{array}$} & \multicolumn{3}{|c|}{$\begin{array}{l}\text { 10-year dbh growth of } \\
\text { surviving trees }\end{array}$} & \multicolumn{3}{|c|}{ 10-year mortality } & \multicolumn{3}{|c|}{10 -year recruitment } \\
\hline & & $\begin{array}{c}\text { Bias } \\
\left(\mathrm{m}^{2} / \mathrm{ha}\right)\end{array}$ & $\begin{array}{l}\text { Relative } \\
\text { bias }\end{array}$ & $\begin{array}{l}\text { RMSE } \\
\left(\mathrm{m}^{2} / \mathrm{ha}\right)\end{array}$ & $\begin{array}{c}\text { Bias } \\
\left(\mathrm{m}^{2} / \mathbf{h a}\right)\end{array}$ & $\begin{array}{c}\text { Relative } \\
\text { bias }\end{array}$ & $\begin{array}{l}\text { RMSE } \\
\left(\mathbf{m}^{2} / \mathbf{h a}\right)\end{array}$ & $\begin{array}{l}\text { Bias } \\
\left(\mathrm{m}^{2} / \mathrm{ha}\right)\end{array}$ & $\begin{array}{c}\text { Relative } \\
\text { bias }\end{array}$ & $\begin{array}{l}\text { RMSE } \\
\left(\mathbf{m}^{2} / \mathbf{h a}\right)\end{array}$ & $\begin{array}{c}\text { Bias } \\
\left(\mathrm{m}^{2} / \mathrm{ha}\right)\end{array}$ & $\begin{array}{c}\text { Relative } \\
\text { bias }\end{array}$ & $\begin{array}{l}\text { RMSE } \\
\left(\mathbf{m}^{2} / \mathbf{h a}\right)\end{array}$ \\
\hline \multirow[t]{6}{*}{$\begin{array}{l}\text { Sugar maple- } \\
\text { yellow birch (FE3) }\end{array}$} & $\begin{array}{l}\text { American } \\
\text { beech }\end{array}$ & -0.06 & $-30.0 \%$ & 1.0 & -0.10 & $-10.1 \%$ & 0.5 & 0.07 & $9.8 \%$ & 1.5 & 0.01 & $16.5 \%$ & 0.3 \\
\hline & Balsam fir & 0.04 & $74.5 \%$ & 1.3 & 0.06 & $10.0 \%$ & 0.5 & 0.01 & $1.2 \%$ & 1.3 & 0.03 & $16.7 \%$ & 0.4 \\
\hline & Red maple & 0.01 & $3.7 \%$ & 1.0 & 0.02 & $2.6 \%$ & 0.5 & -0.02 & $-2.9 \%$ & 1.0 & 0.01 & $7.8 \%$ & 0.4 \\
\hline & Sugar maple & -0.16 & $-13.1 \%$ & 2.6 & 0.04 & $2.1 \%$ & 0.9 & 0.12 & $11.7 \%$ & 2.2 & -0.01 & $-3.4 \%$ & 0.5 \\
\hline & Yellow birch & 0.03 & $18.8 \%$ & 1.4 & 0.04 & $4.9 \%$ & 0.4 & -0.03 & $-5.0 \%$ & 1.5 & 0.01 & $13.0 \%$ & 0.3 \\
\hline & All species & 0.03 & $1.3 \%$ & 4.8 & 0.00 & $0.1 \%$ & 1.4 & 0.03 & $1.0 \%$ & 3.5 & 0.05 & $4.9 \%$ & 1.2 \\
\hline \multirow[t]{6}{*}{$\begin{array}{l}\text { Balsam fir- } \\
\text { yellow birch (MJ2) }\end{array}$} & Balsam fir & 0.10 & $21.7 \%$ & 3.0 & 0.03 & $2.8 \%$ & 0.8 & 0.09 & $5.9 \%$ & 2.2 & 0.15 & $17.2 \%$ & 1.4 \\
\hline & Red maple & 0.06 & $11.5 \%$ & 1.2 & 0.00 & $0.4 \%$ & 0.7 & -0.06 & $-11.8 \%$ & 0.8 & 0.05 & $16.3 \%$ & 0.5 \\
\hline & Trembling aspen & 0.03 & $13.6 \%$ & 1.7 & 0.02 & $1.0 \%$ & 1.1 & -0.02 & $-1.5 \%$ & 2.0 & 0.02 & $12.1 \%$ & 0.6 \\
\hline & White birch & 0.02 & $8.0 \%$ & 1.5 & -0.05 & $-6.3 \%$ & 0.5 & -0.09 & $-12.3 \%$ & 1.4 & 0.01 & $2.6 \%$ & 0.5 \\
\hline & Yellow birch & -0.01 & $-3.0 \%$ & 1.2 & 0.04 & $4.4 \%$ & 0.5 & 0.03 & $6.1 \%$ & 1.2 & 0.01 & $11.0 \%$ & 0.3 \\
\hline & All species & 0.11 & $4.4 \%$ & 4.5 & -0.14 & $-3.8 \%$ & 1.6 & -0.07 & $-1.8 \%$ & 3.4 & 0.18 & $9.5 \%$ & 1.8 \\
\hline
\end{tabular}




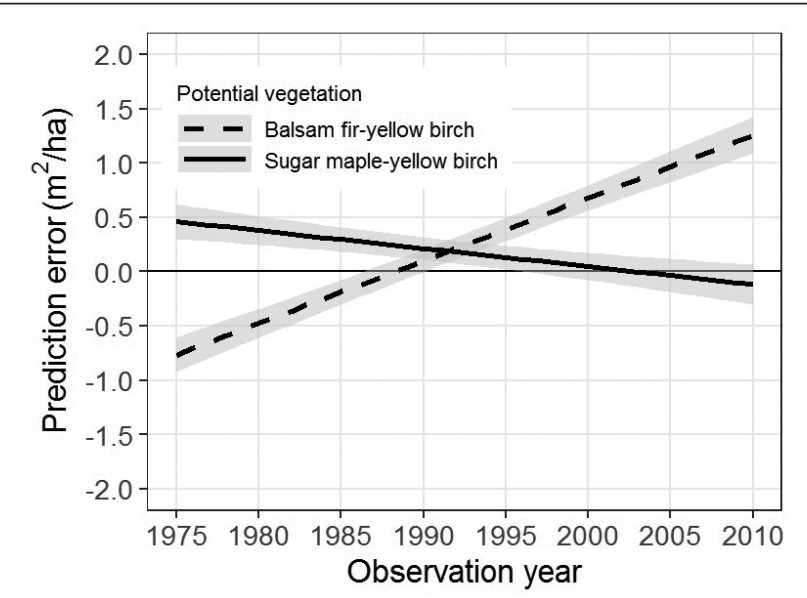

Fig. 3 Ten-year basal area prediction error as a function of observation year for the sugar maple-yellow birch (FE3) and balsam fir-yellow birch (MJ2) potential vegetations, for growth periods that do not follow a partial cut. The gray area represents \pm 1 standard error.

Table 4. Test of fixed effects of the prediction error analysis on species (Sp) basal area, for each potential vegetation, for the Artemis model (DF: numerator degrees of freedom; BA: basal area of the plot at the beginning of the period; Ct: occurrence of a partial cut before the growth interval; Yr: observation year]

\begin{tabular}{lcrrrrr}
\hline & & \multicolumn{2}{c}{$\begin{array}{c}\text { Sugar maple- } \\
\text { yellow birch } \\
\text { (FE3) }\end{array}$} & & & \multicolumn{2}{c}{$\begin{array}{c}\text { Balsam fir- } \\
\text { yellow birch } \\
\text { (MJ2) }\end{array}$} \\
\cline { 3 - 4 } \cline { 6 - 7 } Effect & DF & F value & P value & & F value & P value \\
\hline Yr & 1 & 5.8 & 0.016 & & 52.4 & $<0.001$ \\
Sp & 4 & 58.8 & $<0.001$ & & 204.2 & $<0.001$ \\
$\mathrm{BA}$ & 1 & - & - & & 0.01 & 0.929 \\
$\mathrm{Ct}$ & 1 & 6.6 & 0.010 & & 5.94 & 0.015 \\
$\mathrm{Yr} \times \mathrm{Sp}$ & 4 & 59.0 & $<0.001$ & & 204.8 & $<0.001$ \\
$\mathrm{BA} \times \mathrm{Sp}$ & 4 & - & - & 5.3 & 0.003 \\
\hline
\end{tabular}

Blank spaces appear for variables that were non-significant and removed during variable selection

maple predicted BAEsp varied from $0.5 \pm 0.1 \mathrm{~m}^{2} / \mathrm{ha}$ in 1975 to $-0.8 \pm 0.1 \mathrm{~m}^{2} / \mathrm{ha}$ in 2010 (Fig. 4). The opposite trend was observed for balsam fir, with predicted BAEsp changing from $-0.3 \pm 0.1 \mathrm{~m}^{2} /$ ha to $0.5 \pm 0.1 \mathrm{~m}^{2} /$ ha over the same period. This shift from over- to underestimation of species basal area (BAsp) contributes to weaken the observation year-related pattern observed for BAE (Fig. 3). In absolute value, predicted BAEsp was less than $0.1 \pm 0.1 \mathrm{~m}^{2} /$ ha for the 3 other species (yellow birch, red maple and American beech). For the growth periods that follow a partial cut, predicted BAEsp decreased by $0.11 \mathrm{~m}^{2} / \mathrm{ha}$, compared with periods that do not follow a partial cut (supplementary material S3).

For the MJ2 potential vegetation, BA fixed at $20 \mathrm{~m}^{2} / \mathrm{ha}$ and growth periods that do not follow a partial cut, balsam fir predicted BAEsp varied the most, from $-1.4 \pm 0.1 \mathrm{~m}^{2} / \mathrm{ha}$ in 1975 to $1.7 \pm 0.1 \mathrm{~m}^{2} /$ ha in 2010 . This represents a shift from over- to underestimation of BAsp during the observation period (Fig. 4). Under the same conditions and over the same period, the opposite relationship was observed for white birch BAEsp, for which predictions shifted from $0.5 \pm 0.1 \mathrm{~m}^{2} /$ ha to $-0.4 \pm 0.1 \mathrm{~m}^{2} / \mathrm{ha}$. As was the case for balsam fir in the FE3 potential vegetation, this shift contributes to weaken the observation year-related pattern in BAE. In absolute value, predicted BAEsp was less than $0.1 \pm 0.1 \mathrm{~m}^{2} / \mathrm{ha}$ for the 3 other species (yellow birch, red maple and trembling aspen). When stand basal area increased from 10 to $30 \mathrm{~m}^{2} / \mathrm{ha}$, predicted BAEsp increased by $0.21 \mathrm{~m}^{2} /$ ha for white birch and decreased by $0.26 \mathrm{~m}^{2} /$ ha for balsam fir (supplementary material S3). For growth periods that follow a partial cut, predicted BAEsp was of the same magnitude, but decreased by $0.16 \mathrm{~m}^{2} / \mathrm{ha}$ (supplementary material S3).

\section{Relationship between observation year and species basal area prediction error by component and potential vegeta- tion}

For dbh growth, mortality and recruitment components, BAEsp varied with $\mathrm{Yr}$ and species for both potential vegetations (Table 5). For the FE3 potential vegetation, with BA fixed at $20 \mathrm{~m}^{2} /$ ha, sugar maple predicted BAEsp derived from the dbh growth component varied from $-0.4 \pm 0.02 \mathrm{~m}^{2} /$ ha in 1975 to $-0.4 \pm 0.03 \mathrm{~m}^{2} /$ ha in 2010 . Again, this represents a shift from under- to overestimation of BAsp (Fig. 5). Under the same conditions, the opposite relationship was found for balsam fir, with predicted BAEsp changing from $-0.1 \pm 0.04 \mathrm{~m}^{2} / \mathrm{ha}$ in 1975 to $0.4 \pm 0.04 \mathrm{~m}^{2} / \mathrm{ha}$ in 2010 . In absolute value, when $\mathrm{BA}$ was fixed at $20 \mathrm{~m}^{2} / \mathrm{ha}$, predicted BAEsp derived from the three other species' dbh growth component was less than $0.2 \pm 0.04 \mathrm{~m}^{2} / \mathrm{ha}$. Varying BA from 10 to $30 \mathrm{~m}^{2} /$ ha increased BAEsp by $0.18 \mathrm{~m}^{2} /$ ha for American beech, and decreased it by $0.12 \mathrm{~m}^{2} /$ ha for balsam fir (supplementary material S4).

For balsam fir and growth periods that do not follow a partial cut, predicted BAEsp derived from the mortality component varied from $0.3 \pm 0.1 \mathrm{~m}^{2} / \mathrm{ha}$ in 1975 to $-0.3 \pm 0.1 \mathrm{~m}^{2} / \mathrm{ha}$ in 2010 . The opposite trend was observed for both sugar maple and American beech, with BAEsp changing from respectively $-0.1 \pm 0.1$ and $-0.2 \pm 0.1 \mathrm{~m}^{2} /$ ha in 1975 to respectively $0.4 \pm 0.1$ and $0.3 \pm 0.1 \mathrm{~m}^{2} / \mathrm{ha}$ in 2010 (Fig. 5). For growth periods that follow a partial cut, predicted BAEsp associated to mortality increased by $0.15 \mathrm{~m}^{2} / \mathrm{ha}$ (supplementary material S4).

In absolute value, predicted BAEsp from the recruitment component were less than $0.2 \pm 0.02 \mathrm{~m}^{2} / \mathrm{ha}$ for all species, except for American beech during growth periods that follow a partial cut (Fig. 5, supplementary material S4), in which case the prediction error changed from $-0.06 \pm 0.04 \mathrm{~m}^{2} / \mathrm{ha}$ in 1975 to $0.19 \pm 0.04 \mathrm{~m}^{2} /$ ha in 2010 .

For the MJ2 potential vegetation, when stand basal area was fixed at $20 \mathrm{~m}^{2} / \mathrm{ha}$, balsam fir predicted BAEsp obtained from the dbh growth component varied from -0.2 $\pm 0.03 \mathrm{~m}^{2} /$ ha in 1975 to $0.4 \pm 0.03 \mathrm{~m}^{2} / \mathrm{ha}$ in 2010 which represents a shift from over to underestimation of balsam fir dbh growth during the observation period (Fig. 5). The opposite relationship was found for white birch, for which predicted BAEsp induced by the dbh growth component evolved from 

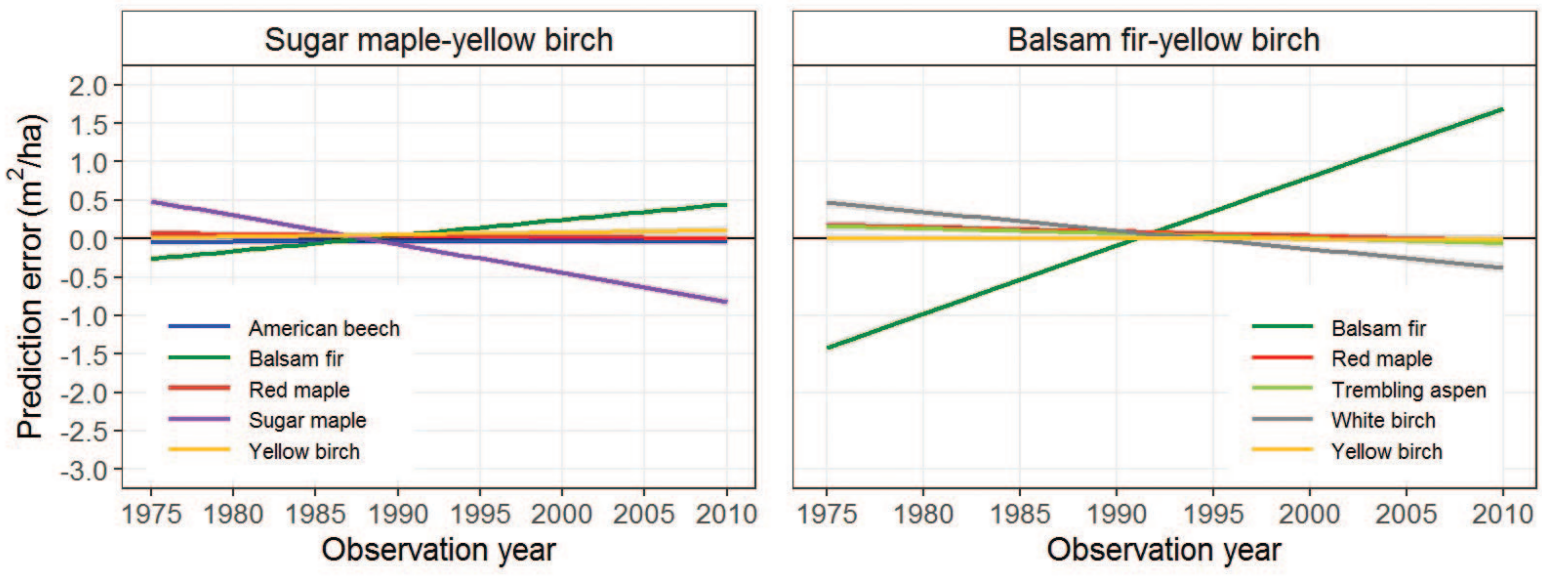

Fig. 4 Ten-year basal area prediction error as a function of observation year for the sugar maple-yellow birch (FE3) and balsam firyellow birch (MJ2) potential vegetations, for growth periods that do not follow a partial cut. The gray area represents \pm 1 standard error. Total basal area at the beginning of the period was fixed at $20 \mathrm{~m} 2 / \mathrm{ha}$.

Table 5. Test of fixed effects of the prediction error analysis on species (Sp) basal area for the dbh growth, mortality and recruitment components of the Artemis model, for each potential vegetation (DF: numerator degrees of freedom; BA: basal area of the plot at the beginning of the period; Yr: observation year; Dt: duration of the growth interval; Ct: occurrence of a partial cut before the growth interval; FE3: sugar maple-yellow birch potential vegetation; MJ2: balsam fir-yellow birch potential vegetation)

\begin{tabular}{|c|c|c|c|c|c|c|c|c|c|c|c|c|c|}
\hline \multirow[b]{3}{*}{ Effect } & \multirow[b]{3}{*}{ DF } & \multicolumn{4}{|c|}{ dbh growth of surviving trees } & \multicolumn{4}{|c|}{ Mortality } & \multicolumn{4}{|c|}{ Recruitment } \\
\hline & & \multicolumn{2}{|c|}{ FE3 } & \multicolumn{2}{|c|}{ MJ2 } & \multicolumn{2}{|c|}{ FE3 } & \multicolumn{2}{|c|}{ MJ2 } & \multicolumn{2}{|c|}{ FE3 } & \multicolumn{2}{|c|}{ MJ2 } \\
\hline & & $F$ value & $P$ value & $F$ value & $P$ value & $F$ value & $P$ value & $F$ value & $P$ value & $F$ value & $P$ value & $F$ value & $P$ value \\
\hline Yr & 1 & 3.0 & 0.085 & 7.7 & 0.006 & 1.71 & 0.193 & 14.1 & $<0.001$ & 47.0 & $<0.001$ & 2.1 & 0.152 \\
\hline$S p$ & 4 & 89.1 & $<0.001$ & 61.4 & $<0.001$ & 8.8 & $<0.001$ & 36.1 & $<0.001$ & 21.2 & $<0.001$ & 249.7 & $<0.001$ \\
\hline $\mathrm{BA}$ & 1 & 1.1 & 0.304 & 7.8 & 0.005 & - & - & 11.6 & 0.001 & 17.8 & $<0.001$ & - & - \\
\hline $\mathrm{Ct}$ & 1 & - & - & - & - & 5.1 & 0.024 & - & - & 8.7 & 0.003 & 10.2 & 0.001 \\
\hline $\mathrm{Dt}$ & - & - & - & - & - & - & - & 19.7 & $<0.001$ & 4.6 & 0.032 & 35.1 & $<0.001$ \\
\hline $\mathrm{Yr} \times \mathrm{Sp}$ & 4 & 89.4 & $<0.001$ & 62.2 & $<0.001$ & 8.8 & $<0.001$ & 35.4 & $<0.001$ & 21.2 & $<0.001$ & 249.7 & $<0.001$ \\
\hline $\mathrm{BA} \times \mathrm{Sp}$ & 4 & 4.8 & 0.001 & 16.5 & $<0.001$ & - & - & 7.7 & $<0.001$ & 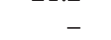 & - & - & - \\
\hline $\mathrm{Ct} \times \mathrm{Sp}$ & & - & - & - & - & - & - & - & & 10.2 & $<0.001$ & - & - \\
\hline $\mathrm{Ct} \times \mathrm{Yr}$ & & - & - & - & - & - & - & - & & 8.6 & 0.003 & - & - \\
\hline $\mathrm{Dt} \times \mathrm{Sp}$ & 4 & - & - & - & - & - & - & 5.9 & $<0.001$ & - & - & 12.7 & $<0.001$ \\
\hline $\mathrm{Dt} \times \mathrm{Yr}$ & 1 & - & - & - & - & - & - & 19.6 & $<0.001$ & - & - & 34.8 & $<0.001$ \\
\hline
\end{tabular}

Blank spaces appear for variables that were non-significant and removed during variable selection

$0.2 \pm 0.03 \mathrm{~m}^{2} / \mathrm{ha}$ in 1975 to $-0.2 \pm 0.03 \mathrm{~m}^{2} / \mathrm{ha}$ in 2010 for the same growth conditions. For all other species, the predicted BAEsp ranged from $0.1 \pm 0.04$ to $0.2 \pm 0.05 \mathrm{~m}^{2} / \mathrm{ha}$ in 1975 , and were almost zero in 2010. Increasing BA from 10 to 30 $\mathrm{m}^{2} /$ ha raised predicted BAEsp induced by the dbh growth component by 0.19 and $0.21 \mathrm{~m}^{2} / \mathrm{ha}$ for red maple and trembling aspen, respectively, and decreases it by $0.21 \mathrm{~m}^{2} / \mathrm{ha}$ for balsam fir (supplementary material S4).

When BA was fixed at $20 \mathrm{~m}^{2} / \mathrm{ha}$, balsam fir predicted BAEsp from mortality changed from $0.7 \pm 0.1 \mathrm{~m}^{2} /$ ha in 1975 to $-0.6 \pm 0.1 \mathrm{~m}^{2} / \mathrm{ha}$ in 2010 . This represents a shift from under- to overestimation of mortality over the period. Under the same conditions, the opposite trend was found for white birch and trembling aspen, with a shift from $-0.5 \pm 0.1 \mathrm{~m}^{2} / \mathrm{ha}$ in 1975 to $0.3 \pm 0.1 \mathrm{~m}^{2} /$ ha in 2010 (Fig. 5). In absolute value, predicted BAEsp from mortality was less than $0.2 \pm 0.1 \mathrm{~m}^{2} / \mathrm{ha}$ for these two species when BA was fixed at $20 \mathrm{~m}^{2} / \mathrm{ha}$. Increasing $\mathrm{BA}$ from 10 to $30 \mathrm{~m}^{2} /$ ha reduced BAEsp predictions by $0.3 \mathrm{~m}^{2} / \mathrm{ha}$ for white birch and by $0.68 \mathrm{~m}^{2} /$ ha for trembling aspen (supplementary material S4).

For balsam fir and growth periods that do not follow a partial cut, BAEsp predictions from the recruitment component varied from $-0.6 \pm 0.03 \mathrm{~m}^{2} / \mathrm{ha}$ in 1975 to $0.9 \pm 0.03 \mathrm{~m}^{2} / \mathrm{ha}$ in 2010 (Fig. 5). By contrast, for the other species, it remained under $0.1 \pm 0.03 \mathrm{~m}^{2} /$ ha in absolute value (Fig. 5). For growth intervals that follow a partial cut, BAEsp predictions from the recruitment component increased by $0.1 \mathrm{~m}^{2} / \mathrm{ha}$ for all species (supplementary material $\mathrm{S} 4$ ). 

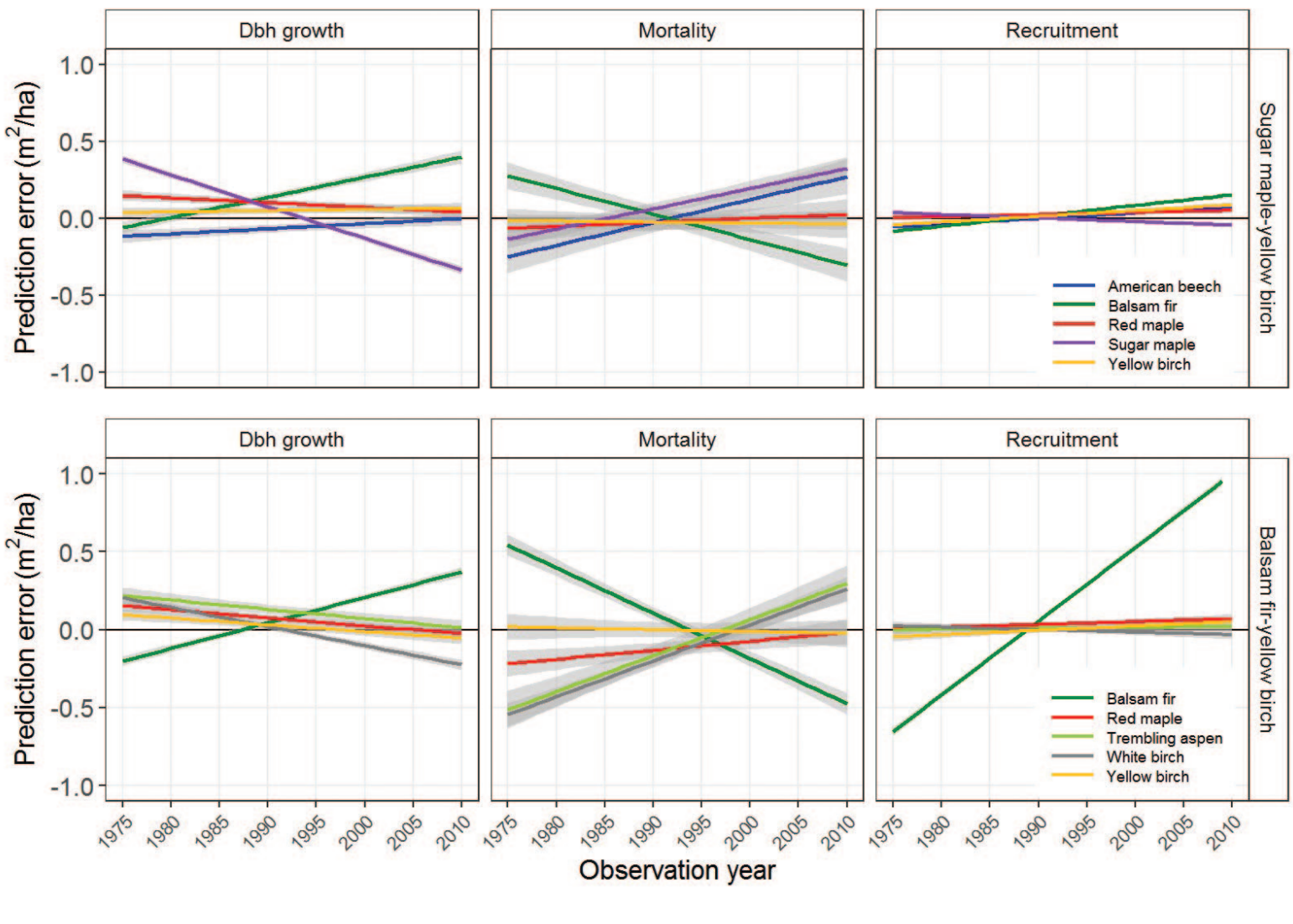

Fig. 5 Ten-year basal area prediction error as a function of observation year, by species, for the dbh growth, mortality and recruitment components of the model, for the sugar maple-yellow birch (FE3) and balsam fir-yellow birch (MJ2) potential vegetations and growth periods that do not follow a partial cut. The gray area represents \pm 1 standard error. Total basal area at the beginning of the period

Residuals of the analysis as well as results for stand BA varying from 10 to $30 \mathrm{~m}^{2} /$ ha are presented as supplementary material S2 to S4.

\section{Discussion}

Even if the model predictions of total BA for the 1975-2010 period are only slightly biased, we found significant relationships between BAE and species, Yr, BA and also Ct. Overall, the effect of BA and Ct was small, except on mortality of red maple and trembling aspen for the MJ2 potential vegetation. For all model components, the largest effects on BAE were the interaction between sugar maple and $\mathrm{Yr}$ for the FE3 potential vegetation, and the interaction between balsam fir and Yr for the MJ2 potential vegetation.

Since usage, value and management decisions all vary according to tree species (Bédard et al. 2017), model users generally seek information not only on total BA or volume, but also on their distribution among the main tree species. The differences between species for the relationship between BAEsp and Yr (Table 4) highlight the importance of evaluating model behavior not only regarding total $\mathrm{BA}$ and volume, but also regarding the distribution of these variables among the main tree species in the stand (Landsberg 2003). These differences also highlight the difficulty for a growth model to accurately predict the growth of each single species in complex mixed stands.

Even if the total BA bias of the model is small (less than 5\%), the relationship between BAE and Yr indicates that model predictions are likely to be biased for simulation periods that extend beyond the year 2010. If the relationship between BAE and Yr is maintained over time, the bias could increase with the duration of the simulation period and cause large prediction errors. In our case, we could expect an overestimation of $\mathrm{BA}$ in the FE3 potential vegetation, especially for sugar maple, and an underestimation in the MJ2 potential vegetation, especially for balsam fir. This concern is often ignored during model validation. Some studies report the bias relative to the simulation period (e.g., Weiskittel et al. 2016), but more often, the short period of observation for the validation data makes it difficult to evaluate a model's longterm error. BA bias has been evaluated for the 2014 version of Artemis over a 40-year simulation period (Power 2016). And we found no time-related pattern for bias when analyzing the effect of simulation time on model errors using starting point measurements from different years. However, this approach could have masked the potential bias associated 
with Yr (Power 2016). In the present study, we used the relationship between BAE of a single growth period and the median observation year of this period, and detected trends in the errors based on the measurement date of the observations. Our results indicate a possible link between the biases and periodic phenomena occurring during the calibration period. This is impossible to do when several simulations start dates are associated with the same simulation period (e.g., Bokalo et al. 2013).

The increasing overestimation of BA in the FE3 potential vegetation (i.e., negative values of $\mathrm{BAE}$ ) results mostly from a combination of the overestimation of sugar maple $\mathrm{dbh}$ growth and the underestimation of mortality trends from 1975 to 2010 . The dbh growth overestimation trend for sugar maple could be associated with reduced growth of trees affected by dieback, as was observed in the last decades (Duchesne et al. 2003). An increase in mortality rates, explained by a combination of biotic and abiotic stresses, has also been reported for sugar maple in the 1990s (Horsley et al. 2000, 2002). These observations are consistent with the Yrrelated pattern in model error. Since no single cause was found in the literature, the decline is probably due to a combination of different stressing factors and could be difficult to correct in an empirical model such as Artemis.

Nonetheless, new predictors could be tested to improve model performance. Data from airborne LiDAR have recently become available for a large part of Quebec's forest. Such data can be used to calculate local topographic indices (Balazy et al. 2019) that can be related to the mortality and growth of sugar maple (Horsley et al. 2000). Recently, a map of soil properties has also become available for the province of Quebec (Sylvain, J.D. submitted). Because sugar maple dieback is related to soil conditions (Duchesne and Ouimet 2003), this new data offer a first avenue to improve the performance of the model. Moreover, since sugar maple dieback is also influenced by climate (Bal et al. 2015), improving the model's climate sensibility could contribute to reducing its bias. Indeed, climate variables such as 30-year mean annual precipitations and annual mean temperature are already used as predictor variables in the model. However, the long observation period for these variables limits the sensibility of the model to climate variations. The change from 30-year means to a period that corresponds to each individual growth interval can be tested to improve model sensibility to climate. However, this would require that the model be coupled with a climate simulator, which would complicate its application.

For American beech, the underestimation of the mortality over recent years could be partly explained by the increased occurrence of beech bark disease (BBD) throughout the study area. BBD was first reported in eastern Quebec in 1965 (Lachance 1983) and has since spread to the western part of the province (MFFP 2017). BBD has caused large-scale mortality in beech stands of the northeastern United States since the second part of the $20^{\text {th }}$ century (Kasson and Livingston 2012). However, the impact of underestimating mortality on total BA bias was limited by a slight trend from overestimation toward underestimation of the dbh growth and recruitment components. BBD, together with the change from diameter-limit to selection cutting, may also explain the trend toward underestimation of American beech recruitment. The death of large beech trees can stimulate sprouting from deceased trees (Nyland et al. 2006), while the retention of a larger proportion of the canopy (and consequently, reduced light availability for the understory) in single-tree selection cutting increases the competitiveness of beech seedlings and saplings against sugar maple (Angers et al. 2005).

Our study also shows that Artemis BAE could be related to the occurrence of $\mathrm{Ct}$ or to BA, as well as to the interaction of these variables with tree species. For the FE3 potential vegetation, the overestimation of BA for growth periods that follow a partial cut (i.e., negative values of BAEsp) is in large part attributable to an underestimation of mortality. This result shows that the use of a binary variable, especially for mortality, is not enough to capture the differences in evolution between plots, whether or not they are subject to a recent cut. In a next version of the model, the binary variable should be tested in interaction with the other predictive variables. The largest effects of BA on BAEsp are on the mortality components for trembling aspen and red maple, where BAEsp increased with stand basal area. This result shows that for some species, the use of basal area of larger trees (BAL) as a competition index does not adequately control the effect of competition on mortality in the model. In a future version of the model, BA should be tested in interaction with tree species as an explanatory variable in the mortality component for the MJ2 potential vegetation. This result also underlines the difficulty for a model like Artemis to produce biasfree estimates of total and species-specific BA.

Of all species, for both potential vegetations, balsam fir showed the largest variation of BAEsp according to Yr. All three model components contribute to a trend from overestimation to underestimation of balsam fir BA in the 19752010 period. On the MJ2 potential vegetation, the components for mortality and recruitment contributed more to bias than the component for dbh growth, while on the FE3 potential vegetation, the dbh growth and mortality components contributed most to the bias. The temporal trend could be explained by a weak control by the model parameters of the effect of spruce budworm defoliation during the severe spruce budworm outbreak that affected the study area from 1965 to 1992 (Gray et al. 2000). Our data show that from 1975 to $1990,79 \%$ of the plots that included spruce or balsam fir trees were affected by at least one year of severe defoliation. During the 1991-2010 period, this proportion fell below 4\%, but $7 \%$ of the plots that had been spared from severe defoliation from 1975 to 1990 had been affected by a light defoliation. The equations for dbh growth (for the FE3 and MJ2 potential vegetations) and mortality (for the MJ2 potential vegetation) include a binary variable that accounts for the presence of four consecutive years with moderate to severe defoliation during the simulation period. This threshold is based on the assumption that maximum mortality occurs after four consecutive years of moderate to severe defoliation (Pothier and Mailly 2006). However, this variable seems unable to capture the entire effect of defoliation by spruce budworm on mortality and diameter growth. Model predictions could be improved by reducing the threshold of consecutive years of defoliation to activate the binary variable for spruce budworm damage, and by taking into account light defoliation in addition to moderate and severe defoliation. Another option could be to use a continuous variable (e.g., 
the number of years of severe defoliation). A growth modifier could also be incorporated into the result of the model equations rather than directly in the equation (Russell et al. 2015). However, at a large scale, detecting all the defoliated forest areas would remain a challenge, since only the most affected areas are surveyed each year.

Forest managers must be aware of the validation results of forest growth models to avoid misled decisions derived from a blind application of model forecasts. In addition to the results of statistical tests, bias, precision and accuracy statistics, species-specific bias and Yr-related trends in bias should be presented as part of the validation results. Species-specific validation is important, because management decisions in mixed and hardwood stands of temperate forests are often based on the main species in the stand, but predictions are generally less reliable at the species level than for total values. In addition, since models are calibrated using data from the past and used to predict future forest characteristics, temporal trends in biases may remain through simulation periods and be amplified in model predictions.

\section{Conclusion}

The overall BA bias was found to be small in the 2014 version of Artemis model over two of its main territories of application. However, the relationship between observation year and 10-year BA prediction error revealed trends toward overestimation for sugar maple, and toward underestimation for balsam fir. Model users should be aware that these trends could bias the model's predictions. Continuous validation is required to improve models. With our analysis, we identified weaknesses in Artemis as well as potential solutions to correct them. Some of these, such as accounting for light spruce budworm defoliation, are rather straightforward, while others, such as accounting for the increasing overestimation of sugar maple, are more challenging.

\section{Acknowledgments}

The authors would like to thank Ms. Josianne DeBlois, Ms. Denise Tousignant and Mr. Filip Havreljuk from the Direction de la recherche forestière for their suggestions on an earlier version of the manuscript, Mr. Jean Noël from the Direction de la recherche forestière for producing Fig. 1 and Mr. Carl Bergeron from the Direction des inventaires forestiers for formatting the database. We also like to thank the two anonymous reviewers and the associate editor for providing useful comments on the manuscript. This work was funded by the Ministère des Forêts de la Faune et des Parcs du Québec (project number: 142332123).

\section{References}

Akaike, H. 1973. Information theory as an extension of the maximum likelihood principle. In: Second international symposium on information theory, Petrov, B.N. and C. F. (eds.). Akademiai Kiado. pp. 267-281.

Angers, V.-A., C. Messier, M. Beaudet and A. Leduc. 2005. Comparing composition and structure in old-growth and harvested (selection and diameter-limit cuts) northern hardwood stands in Quebec. Forest Ecol. and Manag. 217(2-3): 275-293.

Bal, T.L., A.J. Storer, M.F. Jurgensen, P.V. Doskey and M.C. Amacher. 2015. Nutrient stress predisposes and contributes to sugar maple dieback across its northern range: A review. Forestry 88(1): 64-83.
Balazy, R., A. Kaminska, M. Ciesielski, J. Socha and M. Pierzchalski. 2019. Modeling the effect of environmental and topographic variables affecting the height increment of Norway spruce stands in mountainous conditions with the uses of LiDAR Data. Remote Sensing 11(20):15.

Bédard, S. and Z. Majcen. 2003. Growth following single-tree selection cutting in Québec northern hardwoods. For. Chron. 79(5): 898-905.

Bédard, S., I. Duchesne, F. Guillemette and J. DeBlois. 2017. Predicting volume distributions of hardwood sawn products by tree grade in eastern Canada. Forestry 91(3): 341-353.

Bokalo, M., K.J. Stadt, P.G. Comeau and S.J. Titus. 2013. The validation of the mixedwood growth model (MGM) for use in forest management decision making. Forests 4(1):1-27.

Condés, S. and F. Garcia-Robredo. 2012. An empirical mixed model to quantify climate influence on the growth of Pinus halepensis Mill. stands in South-Eastern Spain. Forest Ecol. and Manag. 284:59-68.

Duchesne, L. and R. Ouimet. 2009. Present-day expansion of Americn beech in northeastern hardwood forests: Does soil base status matter? Can. J. For. Res. 39: 2273-2282.

Duchesne, L., R. Ouimet and C. Morneau. 2003. Assessment of sugar maple health based on basal area growth pattern. Can. J. For. Res. 33: 2074-2080.

Dufour-Kowalski, S., B. Courbaud, P. Dreyfus, C. Meredieu and F. de Coligny. 2012. Capsis: an open software framework and community for forest growth modelling. Ann. For. Sci. 69(2): 221-233. Ex, S.A. and F.W. Smith. 2014. Evaluating Forest vegetation simulator performance for trees in multiaged ponderos pine stands, Black Hills, USA. For. Sci. 60(2): 214-221.

Fontes, L., J.D. Bontemps, H. Bugmann, M. Van Oijen, C. Gracia, K. Kramer, M. Lindner, T. Rotzer and J.P. Skovsgaard. 2010. Models for supporting forest management in a changing environment. For. Syst. 19: 8-29.

Fortin, M. and L. Langevin. 2010. ARTÉMIS-2009 : un modèle de croissance basé sur une approche par tiges individuelles pour les forêts du Québec. Gouvernement du Québec, Québec, Ministère des Ressources naturelles et de la Faune. Mémoire de recherche forestière no 156, Québec, Qc. 48 pp. Available online at https:// mffp.gouv.qc.ca/publications/forets/connaissances/recherche/ Fortin-Mathieu/Memoire156.pdf.

Gray, D.R., J. Régnière and B. Boulet. 2000. Analysis and use of historical patterns of spruce budworm defoliation to forecast outbreak patterns in Quebec. For. Ecol. and Manag. 127: 217-231.

Hennigar, C.R. and D.A. MacLean. 2010. Spruce budworm and management effects on forest and wood product carbon for an intensively managed forest. Can. J. For. Res. 40: 1736-1750.

Horsley, S.B., R.P. Long, S.W. Bailey, R.A. Hallett and T.J. Hall. 2000. Factors associated with the decline disease of sugar maple on the Allegheny Plateau. Can. J. For. Res. 30(9): 1365-1378.

Horsley, S.B., R.P. Long, S.W. Bailey, R.A. Hallett and P.M. Wargo. 2002. Health of eastern North American sugar maple forests and factors affecting decline. North. J. Appl. For. 19(1): 34-44.

Kasson, M.T. and W.H. Livingston. 2012. Relationships among beech bark disease, climate, radial growth response and mortality of American beech in northern Maine, USA. For. Pathol. 42: 199-212. Korzukhin, M.D., M.T. TerMikaelian and R.G. Wagner. 1996. Process versus empirical models: Which approach for forest ecosystem management? Can. J. For. Res 26(5): 879-887.

Lachance, D. 1983. Status of beech bark disease in the province of Québec. In: I.U.F.R.O. Beech bark disease working party conference, Houston, D.R., and D. Wainhouse (eds.). USDA Forest Service, Hamden, Ct. pp. 18-20.

Landsberg, J. 2003. Modelling forest ecosystems: State of the art, challenges, and future directions. Can. J. For. Res. 33(3): 385-397.

MacLean, D.A., K.P. Beaton, K.B. Porter, W.E. MacKinnon and M.G. Budd. 2002. Potential wood supply losses to spruce budworm 
in New-Brunswick estimated using the SpruceBudworm Decision Support System. For. Chron. 78(5): 739-750.

MacLean, D.A., P. Amirault, L. Amos-Binks, D. Carleton, C. Hennigar, R. Johns and J. Regniere. 2019. Positive results of an early intervention strategy to suppress a spruce budworm outbreak after five years of trials. Forests 10(5):19.

MFFP. 2014. Réseaux des placettes échantillons permanentes du Québec méridional. Gouvernement du Québec, Ministère des Forêts, de la Faune et des Parcs, Direction des inventaires forestiers. 10 pp.

MFFP. 2017. Insectes, maladies et feux dans les forêts du Québec. Gouvernement du Québec, Ministère des Forêts, de la Faune et des Parcs, Direction de la protection des forêts. $64 \mathrm{pp}$.

Miller, D.E. and S.A. Watmough. 2009. Soil acidification and foliar nutrient status of Ontario's deciduous forest in 1986 and 2005. Environ. Pollut. 157(2): 664-672.

MRNFP. 2003. The ecological land classification hierarchy. Gouvernement du Québec, Ministère des Ressources naturelles, de la Faune et des Parcs., Direction des inventaires forestières, Québec (Quebec). 3 pp.

Nyland, R.D., A.L. Bashant, K.K. Bohn and J.M. Verostek. 2006. Interference to hardwood regeneration in northeastern North America: Ecological characteristics of American beech, striped maple, and hobblebush. North. J. Appl. For. 23(1): 53-61.

Ouranos. 2015. Sommaire de la synthèse des connaissances sur les changements climatiques au Québec. Ouranos. 13 pp.

Penner, M., M. Woods, J. Parton and A. Stinson. 2008. Validation of empirical yield curves for natural-origin stands in boreal Ontario. For. Chron. 84(5):704-717.

Pothier, D. and D. Mailly. 2006. Stand-level prediction of balsam fir mortality in relation to spruce budworm defoliation. Can. J. For. Res. 36:1631-1640.

Pothier, D., D. Mailly and S. Tremblay. 2005. Predicting balsam fir growth reduction caused by spruce budworm using large-scale historical records of defoliation. Ann. For. Sci. 62: 261-267.

Power, H. 2016. Comparaison des biais et de la précision des estimations des modèles Artémis-2009 et Artémis-2014 pour la surface terrière des peuplements forestiers avec et sans coupe partielle, sur une période de 40 ans. Gouvernement du Québec, Ministère des Forêts, de la Faune et des Parcs, Direction de la recherche forestière, Note de recherche forestière no 143 , Québec, Qc. 21 pp. Available online at https://mffp.gouv.qc.ca/documents/forets/connaissances/ recherche/Note143.pdf.
Pretzsch, H. 2009. Forest dynamics, growth and yield from measurement to model. Springer-Verlag, Berlin, Germany.

Pretzsch, H., R. Grote, B. Reineking, T. Rotzer and S. Seifert. 2008. Models for forest ecosystem management: A European perspective. Ann. Bot.-London 101(8): 1065-1087.

Russell, M.B., A.R. Weiskittel and J.A. Kershaw. 2015. Benchmarking and calibration of forest vegetation simulator individual tree attribute predictions across the northeastern United States. North. J. Appl. For. 30(2): 75-84

SAS Institute Inc. 2018. SAS/STAT ${ }^{\varpi} 15.1$ User's Guide. Cary, NC: SAS Institute Inc.

Soares, P., M. Tome, J.P. Skovsgaard and J. K. Vanclay. 1995. Evaluating a growth-model for forest management using continuous forest inventory data. For. Ecol. Manag. 71(3): 251-265.

Stage, A.R. 2003. How forest models are connected to reality: Evaluation criteria for their use in decision support. Can. J. For. Res. 33: 410-421.

Vanclay, J.K. and J. P. Skovsgaard. 1997. Evaluating forest growth models. Ecol. Model. 98:1-12. Weiskittel, A.R., D.W. Hann, J.A. Kershaw Jr, and J.K. Vanclay. 2011. Forest Growth and yield modeling. Wiley-Blackwell, West Sussex, UK. 415 pp.

Weiskittel, A., C. Kuehne, J.P. McTague and M. Oppenheimer. 2016. Development and evaluation of an individual tree growth and yield model for the mixed species forest of the Adirondacks Region of New York, USA. For. Ecosyst. 3:17.

Yang, Y., R.A. Monserud and S. Huang. 2004. An evaluation of diagnostic tests and their roles in validating forest biometric models. Can. J. For. Res. 34:619-629.

\section{List of supplementary material}

S1 Number of observations per year for each potential vegetation.

S2 Residuals of the relationship between observation year and total basal area prediction error by potential vegetation.

S3 Analysis of the relationship between observation year and species basal area prediction error for FE3 and MJ2 potential vegetation.

S4 Analysis of the relationship between observation year and species basal area prediction error by component for FE3 and MJ2 potential vegetation. 